\title{
INCREASING THE CAPACITY OF KOPASTI AS A CLEAN WATER MANAGEMENT FROM SOURCES IN PASIRJATI, UJUNGBERUNG DISTRICT, BANDUNG.
}

\author{
Nyi Raden Ruyani ${ }^{1}$, Mira Rosana Gnagey ${ }^{2}$, Ahtu Duriat ${ }^{3}$, Ediyanto ${ }^{4}$ \\ Public Administration, FISIP UNPAS ${ }^{1,2,3,4}$ \\ ruyani@unpas.ac.id
}

\begin{abstract}
The clean water crisis began to emerge recently in the city of Bandung, especially when the water supply did not meet the needs of the residents, resulting in turmoil. Not only users and the government, but also PDAM as a provider are in trouble. Itinerant traders are also experiencing difficulties because demand continues to soar, while water sources are limited. According to Geodesy Expert from the Bandung Institute of Technology, Heri Andreas, the city of Bandung is already experiencing a clean water crisis and currently the condition is getting worse. Without the intervention of the Government and Regional Governments in managing access to clean water, it is certain that the fate of big cities will have the potential for social conflict due to access to clean water. Springs as one of the shared water sources require management that includes mutual understanding and rules, service management and continuous maintenance. Increasing the Capacity of Kopasti to Manage Clean Water from Springs in Pasirjati Village, Ujungberung District, Bandung City through socialization, training and facilitation is expected to provide solutions faced by partners, especially with regard to opening a common understanding of the need for conservation efforts, protection of springs and management of archive administration and facilitation of work facilities.
\end{abstract}

Keywords: clean water management, training, socialization, facilitation 


\section{A. Introduction}

Drinking water is a basic human need. Access to drinking water is one of the targets in the Sustainable Development Goals (SDGs), which is stated in the sixth goal, namely by 2030 all communities must have access to drinking water. The sixth goal in the SDGs is related to other goals, including the 11th goal, namely sustainable cities and communities. In Indonesia, the fulfillment of the need for drinking water for the community is carried out by the government in the form of a public drinking water supply system by the Regional Drinking Water Company (PDAM). However, PDAM service coverage is currently still low. The fulfillment of water needs for people who are not served by the public system is carried out individually and communally (groups).

Communal systems are generally community-based systems. Communitybased systems play an important role in increasing access to drinking water. In order to improve access to drinking water, not only investment and infrastructure development are needed, but also the willingness of the community in groups to carry out self-supply as a temporary strategy (Bisung et al., 2014). Community-based systems have several forms, namely those developed by the community independently and those developed with government assistance. Community-based systems are widely found in developing countries (Hope, 2013; Schouten \& Moriarty, 2015). This approach is widely used because of the limited supply of drinking water by the government or the private sector. This system emphasizes community involvement in operation and maintenance (Bakker, 2008).

The clean water crisis began to emerge recently in the city of Bandung, especially when the water supply did not meet the needs of the residents until it became volatile. Not only the citizens and the government, but also PDAM as the provider is in trouble. Itinerant traders are also experiencing difficulties as demand continues to soar, while water sources are limited. In general, Indonesia's water reserves reach 2,530 km3 / year which is included in one of the countries that has the richest water reserves in the world. In other data, the availability of water in Indonesia reaches $15,500 \mathrm{~m} 3$ per capita per year. This figure is still far above the average water availability in the world which is only $8,000 \mathrm{~m} 3$ per year. Even so, Indonesia is still experiencing a 
scarcity of clean water, especially in big cities. According to Geodesy Expert from the Bandung Institute of Technology, Heri Andreas, the city of Bandung is already experiencing a clean water crisis and currently the condition is getting worse. The city of Bandung requires about 26,938 liters of water per second, but only 17,700 liters of water per second are available. In addition, according to the Working Group on Drinking Water and Environmental Sanitation, the availability of water in Java was only 1,750 m3 per capita per year in 2010 and continued to decline to $1,200 \mathrm{~m} 3$ per capita per year in 2020, even though the minimum adequacy standard is 2,000 $\mathrm{m} 3$ per capita per year.

Various causes of the clean water crisis in big cities in Indonesia. First, the population problem. Second, the service coverage of PDAMs in all corners of Indonesia is still small. In general, clean water services in urban areas in Indonesia until 2018 only reached $39 \%$ or 33 million people, which means that around 119 million people still do not have access to clean water. Third, the effect of changing seasons which causes uneven water supply. The alternation between the rainy season and the dry season in Indonesia looks very contrasting where in the rainy season there are floods but during the dry season there is a crisis of clean water. According to Swyngedouw (2014) the success of a city is highly dependent on its ability to overcome environmental problems, especially in the provision of clean water. Without the intervention of the Government and Regional Governments in managing access to clean water, it is certain that the fate of big cities will have the potential for social conflict due to access to clean water. Such concerns are not based on mere assumptions. A study conducted by Wirsing, Stoll, and Jasparro (2015) entitled International Conflict over Water Resources in Himalayan Asia concluded that springs in the Himalayas that flow to several countries in Central Asia will potentially lead to conflicts between countries. This study also strengthens the Stoll Study (2018) which concludes that in the future Middle Eastern countries traversed by the Euphrates and Tigris rivers have the potential to conflict with each other to compete for clean water in the two rivers. Based on this, the imbalance in population and water availability has the opportunity to become a new chapter of global and local conflicts in this century. Like fuel oil, there is no substitute for water resources. In addition, 
global concerns about water scarcity are also due to the prediction by Gardner-Outlaw and Engelman (1997), that by 2050 it is predicted that 1 in 4 people will be affected by a lack of clean water.

Pasir Jati is one of the five villages in the Ujungberung District. Pasir Jati Village has several springs where since 1975 one of these springs has been a supplier of clean water needs to the Bandung city area through PDAM Tirtawening, Bandung City. Pasir Jati Village has an area of $\pm 123.432 \mathrm{Ha}$. Kelurahan Pasir Jati consists of 12 RW and 51 RT with a population of 4.4 .74 men and 4,654 women with 2265 families and a density of 8,656 people/km. Pasir Jati village, in terms of morphology, is found in areas with mountainous morphology with an altitude of \pm 700 -800 masl. In terms of land use, Pasir Jati Village is dominated by settlements, although there are other small areas in the form of protected land such as parks. (Source: Monograph of Pasir Jati Village in 2019). However, the obstacle is that there is a problem with the development of the potential of the Pasir Jati Village area which affects population growth which is increasing every year. Taking into account the increasing rate of population growth, which ranges from 1.6-1.2\% per year, it will affect the need for clean water and efforts to fulfill clean water.

Most of the community's water needs in Pasir Jati Village come from groundwater and springs. The clean water facilities in Pasir Jati consist of the installation of Clean Water Facilities (SAB), dug wells, hand pump wells and electric pumps. Other springs in Pasir Jati already have clean water facilities in the form of spring catcher buildings and public hydrants. Seeing the condition of the kelurahan that still requires clean water facilities, the alternative of obtaining water sources from local springs is an option that can be a solution in overcoming the shortage of clean water in this case the need for facilities and infrastructure that are able to support it.

The existence of partners with a clean water system has an impact on the environment, especially in Pasirjati. Community participation in a complete understanding of the existence of springs can foster a sense of belonging to the existence of clean water sourced from these springs (Darmawan and Fadjarajani, 2016; Lian, 2018). 
Kopasti as a Clean Water Management was initiated by the owner of the Otobus DS Company which has been around for almost 51 years since 1970. The location of the spring in Cilaja Village is on the land of the family of the owner of the DS Otobus Company. which is located on privately owned land, was registered as a Clean Water Manager in 2006 so that the water can be used for personal use as well as for many people (the legal umbrella for water management, which is the right of life for many people, is managed by the State Forestry Public Company, Perum Perhutani). Regional Division of West Java and Banten KPH North Bandung, based on the Partnership Agreement on Forestry Utilization of Water Utilization Business Environmental Services, which is extended every 2 (two) years.

Since operating the Clean Water Management Kopasti, it has a total of 250 customers, but now there are only 60 customers. Among other things, switching to another manager managed by a local village, with cheaper retribution and maintenance of the network which is considered newer.

However, because the location of the springs is quite far (approximately almost
$4 \mathrm{~km}$ must be taken by foot). Water from the spring is channeled through a hose to a reservoir in Kampung Cilaja, from the reservoir in the form of a tub and then flows into a torn where it can then be flowed to customers through a hose. The requirement as a customer is to pay for the replacement of the cost of the hose facility from the shelter to their respective homes and the cost of using water for one month seen from the water usage meter installed in the customer's house. Schematically the flow of clean water from the spring to the reservoir then to Torn 1, Torn 2 and Torn 3 (according to) the area that connects to each SR (House Connection) is presented in Figure 1.

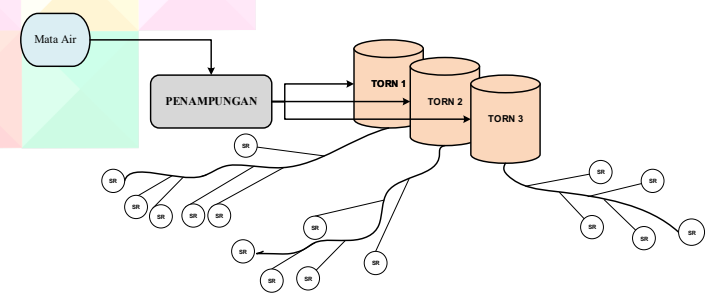

Figure 1. Flow of Clean Water from Springs Source: Kopasti Manager, 2021

The cost of this connection is $\mathrm{Rp}$. $1,000,000.00$ (one million rupiah) for the installation of hoses and water meters, with the calculation of the tariff for the price of clean water used by customers is presented in Table 1. 
Table 1. Cost of Clean Water Usage

\begin{tabular}{|r|c|c|}
\hline No & $\begin{array}{c}\text { Usage } \\
\left(\mathrm{m}^{3}\right)\end{array}$ & $\begin{array}{c}\text { Cost } \\
(R p)\end{array}$ \\
\hline 1 & $0-10$ & $3.000,00$ \\
\hline 2 & $11-20$ & $4.000,00$ \\
\hline 3 & $21-30$ & $5.000,00$ \\
\hline 4 & $>$ & $6.000,00$ \\
& 30 & \\
& \\
\hline
\end{tabular}

Source: Kopasti Manager, 2021

Payment of water usage no later than the 20th of each month, if late, a fine of Rp. $5,000.00$ (five thousand rupiah). If 3 (three) months are not paid, the connection will be disconnected, if it will be reconnected, a new connection fee will be charged and must pay off the previous arrears.

The clean water management administrative officer consists of 2 (two) people, one is doing mobile records between the 1 st to 5 th of each month and the other is in charge of operating the computer. Presented in Figure 2 is a water meter (water meter) which shows how much clean water is used by customers for one month. Then the data is entered by the officer in the office to the computer to be recorded and the receipt is made manually filled in. The officer who collects will be on duty to go around again starting from the 10th to the 20th of every month. Field Officers consist of 4 (four) people who are tasked with carrying out routine maintenance and receiving customer complaints on a rotating basis. Most often the water does not flow because there are obstacles or leaks that occur in the hose connecting the water flow from the reservoir to the house of the clean water customer.

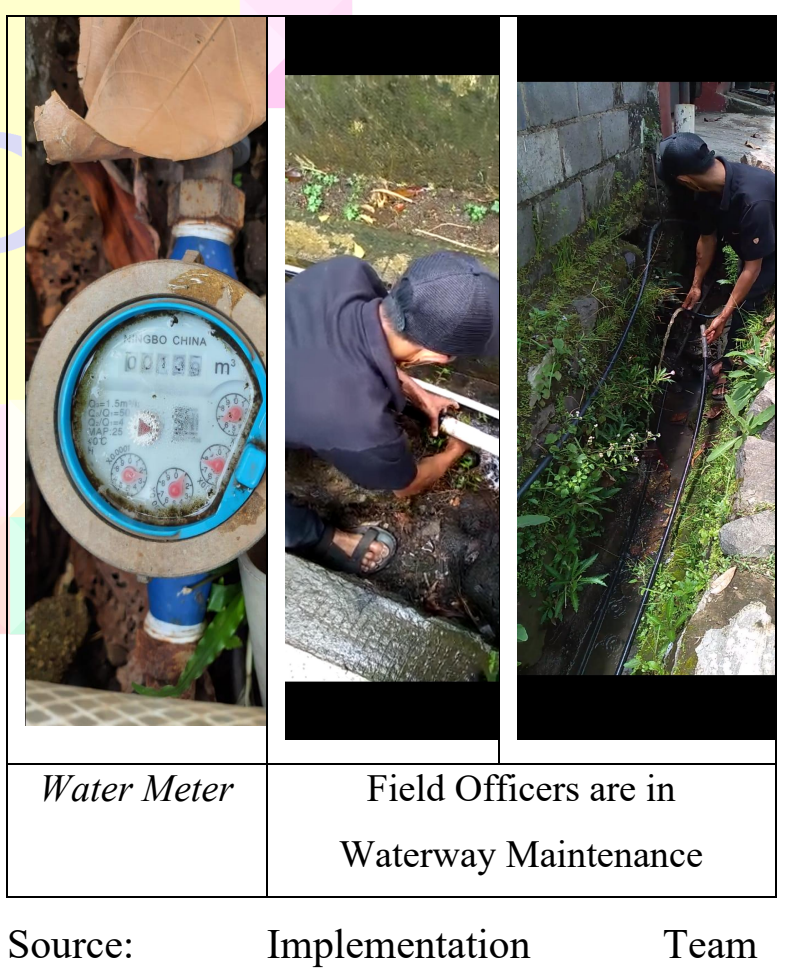

Documentation, 2021

Problems faced in general by managers of clean water sourced from springs, among others, are related to the inadequate understanding of the user community about systemic knowledge 
related to the sustainability of water sources from springs which are an effort to protect springs and stakeholders managing water resources, both the role of the government and the government. private sector that has the opportunity to manage and provide services to the user community. The same thing happened to the Clean Water Management Kopasti, which became the main problems it faced, namely; (1) Knowledge, the community that uses clean water from springs managed by the Clean Water Management Kopasti still doesn't seem to understand the knowledge about spring conservation; (2) Work Facilities, Kopasti Clean Water Management as the manager of clean water sources sourced from springs does not yet have management and work facilities for field officers who support excellent service to customers (community users of clean water sourced from springs).

\section{B. Method of Implementation}

The implementation method in this activity is carried out through socialization, training and facilitation activities. Schematically, the stages of this activity are described as follows: a. Preparation; in the preparation stage, the team mobilized the implementing team, conducted a literature study on spring protection and clean water management, activity approaches and methodologies as well as strengthening work plans.

b. Implementation; in the implementation phase, the team performs task division and initial briefing, carries out socialization, training and facilitation. then make implementation documentation during the activity.

c. Monitoring and evaluation; in this stage the team evaluates the implementation of socialization, training and facilitation, as well as making conclusions and suggestions on the implementation of activities.

d. External arrangement; the last step, the team compiled a report and made a scientific article about this activity.

The implementation method in this activity is carried out through socialization, training and facilitation activities. The implementation of this activity takes into account the 5W $1 \mathrm{H}$ concept; what activity, who (who) is the target of the activity, where (where) the activity is carried out, when 
(when) the activity is carried out, why (why) the activity is carried out, and how (how) the activity is carried out. The type of partner in this activity is active, cooperative, and productive with the type of partner group managing clean water sourced from springs (Kopasti) participating in the form of willingness to provide time and place to be able to share useful knowledge and ideas or participate in other forms. In this activity, there are aspects that are evaluated such as:

1. Strength; What is owned by Kopasti is that it has been almost 15 (fifteen) years as part of the clean water provider for the community and has the facilities and authority to manage clean water sourced from springs.

2. Weaknesses; faced by actors managing clean water sourced from springs (Kopasti), namely the lack of ability to educate the public in conserving springs; lack of administrative management and work facilities in providing services to customers.

3. Opportunity; namely the opportunity between the manager of clean water sourced from springs (Kopasti) and the Community Partnership Program Team for the Public Administration Study
Program of FISIP UNPAS to make the development program a success.

The sustainability of the Community Partnership Program for the Public Administration Study Program of FISIP UNPAS based on the results of monitoring and evaluation carried out needs to be followed up with continuous efforts to resocialize the urgency of maintaining the existence of springs with a range of the number of people receiving socialization plus the number and facilitation of service administration to customers who use clean water starting from orderly administration and computer system equipment which started to be based on water use application programs and clean water payment receipts (no longer using handwritten receipts manually but united with the computer system every month starting from inputting water usage).

\section{Result and Discussion}

The results of the implementation of the Community Service Capacity Building for Clean Water Management Sourced from Springs in Pasir Jati Village, Ujungberung District, Bandung City, financed by the UPT Research Expertise Program, Community Service Publication and Lecturer 
Recognition (P2MPRD) FISIP UNPAS Bandung.

which can take place as planned, namely:

The outputs from the implementation

1. Ngawangkong Cimata, meeting as a of the Clean Water Management Kopasti vehicle for socializing the urgency of spring conservation to Kopasti customers who manage clean water sourced from springs, who live near water reservoirs in Cilaja Village, on Tuesday, April 6, 2021, starting at 10.00 WIB ending until 13.00 WIB closed with a friendly lunch together at the Gazebo Water Reservoir from the Spring in Kampung Cilaja. It was originally attended by 20 (twenty) people consisting of local RT/RW Management, Karang Taruna Management, Posyandu women who are also Kopasti customers who manage clean water living around water reservoirs in Kampung Cilaja, but only 10 person were able to attend.

Capacity Building activity sourced from springs in Pasir Jati Village, Ujungberung City, Bandung City, which are funded by the UPT Research Expertise Program, Community Service Publication and Lecturer Recognition (P2MPRD) FISIP UNPAS are in the form of:

1. Ngawangkong Cimata material, meeting as a vehicle for socializing the urgency of spring conservation for people who use clean water from springs;

2. Training materials for simple administration of customer bookkeeping management;

2. Delivery of facilitation in the form of parasitic jackets for Clean Water Management Kopasti Employees as many as 6 (six) people (2 administrative staff, 4 field workers) at the closing of the Ngawangkong Cimata activity;

3. Simple administrative training for managing customer bookkeeping is carried out from 7 to 9 April 2021 simultaneously at the Clean Water Management Kopasti Office at the office located on Jl. Raya Sindanglaya

3. Facilitation of work facilities for Kopasti employees who manage clean water from springs;

4. Draft scientific article on Increasing the Capacity of Kopasti to Manage Clean Water from Springs in Pasir Jati Village, Ujungberung District, Bandung City.

\section{Conclusion}

The results of the implementation of the Clean Water Management Kopasti 
Capacity Building Activities sourced from springs in the Pasir Jati Village, Ujungberung District, Bandung City which were funded by the UPT Research Expertise Program, Community Service Publication and Lecturer Recognition (P2MPRD) FISIP UNPAS are as follows:

1. The joint efforts of all stakeholders (government, private sector, academia, businessmen and the community themselves) in building a shared responsibility for water spring conservation becomes an undeniable urgency. Cimata is certainly not wanted by all of us in future generations when the condition of the springs is getting less and it can even be said to be extinct where the spring is one of the sources of water for the needs of human life. Paying attention to Ngawangkong Cimata chatting together as a vehicle for socializing the urgency of spring conservation is one of the concerns of the academic community of the Public Administration Study Program of FISIP UNPAS in today's need for clean water which can be said to be quite expensive;

2. Work facilities and provision of job training for all Kopasti employees who manage clean water are one of the means that can provide excellent service to customers of Kopasti that manages clean water as users of clean water sourced from springs;

Meanwhile, for suggestions from the implementation of the Capacity Building for the Kopasti Capacity Building for Clean Water Managers sourced from springs in Pasir Jati Village, Ujungberung District, Bandung City.

1. The urgency of spring conservation efforts needs to be carried out in a sustainable and holistic manner across generations from all stakeholders (government, private sector, academics, entrepreneurs and the community themselves);

2. Understanding of simple bookkeeping administration is a necessity for everyone, especially for those who provide public services.

Bookkeeping administration needs to be one of the mandatory basic teaching materials, namely as a form of getting used to recording and keeping in its place;

3. Fulfillment of work facilities, 
especially those related to basic needs as the fulfillment of the needs of human life.
Parahita, D., "Penyediaan Air Bersih Oleh Komunitas", Buletin Perkotaan dan Perdesaan, PU, 2003.

\section{REFERENCES}

Darmawan, Darwis dan Fadjarajani, Siti, 2016, Hubungan Antara Pengetahuan Dan Sikap Pelestarian Lingkungan Dengan Perilaku Wisatawan Dalam Menjaga Kebersihan Lingkungan (Studi di Kawasan Objek Wisata Alam Gunung Galunggung Desa Linggajati Kecamatan Sukaratu Kabupaten Tasikmalaya), Jurnal Geografi, Volume 4 Nomor 1 April 2016 ISSN $1907-302$

Lian, Lian G Otaya, 2018. Pengetahuan, Sikap Dan Tindakan Masyarakat Terhadap Penggunaan Jamban Keluarga (Studi Kasus Di Desa Ilomangga Kecamatan Tabongo Kabupaten Gorontalo), file:///C:/Users/Lenovo/Downloads/8 56-849-1-PB.pdf

Masduqi, A., N. Endah, E. S. Soedjono, dan W. Hadi., "Teknologi Penyediaan Air Bersih Perdesaan: Studi Kasus di Kabupaten Mojokerto”, 2010.

Masduqi, A., N. Endah dan E. S. Soedjono., "Sistem Penyediaan Air Bersih Pedesaan Berbasis Masyarakat: Studi Kasus HIPPAM di DAS Brantas Bagian Hilir", Seminar Nasional Pascasarjana VIII - ITS, 13 Agustus 2008, Surabaya.

Masduqi, A., N. Endah, E. S. Soedjono, dan W. Hadi., "Capaian Pelayanan Air Bersih Perdesaan Sesuai Millenium Development Goals-Studi Kasus di Wilayah DAS Brantas”, 2010. 